\title{
Cerebral venous thrombosis and Covid 19: Literature review
}

\begin{abstract}
Introduction: Severe Acute Respiratory Syndrome-Coronavirus 2 (SARS-CoV-2) was first detected in December 2019 in the city of Wuhan, China, and has since taken on worldwide proportions. It is known that individuals with Coronavirus disease-19 (COVID-19) have systemic clinical manifestations. Among the multisystemic effects, cerebral venous thrombosis (CVT) is responsible for high mortality rates. In this sense, understanding the association between CVT and SARS-CoV-2 infection directly impacts the disease's morbidity and mortality.
\end{abstract}

Methodology: Literature review in the PubMed and Embase databases, with the following search terms: "COVID-19", "SARS-CoV-2", "Venous thromboembolism", "Thrombosis", "Cerebral Venous Thrombosis", "Intracranial Sinus Thrombosis" and "Cranial Sinus Thrombosis". The selected articles were written in English, which addressed the various aspects of COVID-19.

Results and discussion: CVT are a rare complication of COVID-19, with an incidence between 0.02 to $1 \%$ of hospitalized patients. However, it can reach about $75 \%$ of mortality in affected individuals. Pathophysiology seems to be associated with the state of hypercoagulability and the systemic inflammatory process resulting from viral infection. Thus, recent studies show a consensus on the early anticoagulation of patients affected by the virus, to reduce mortality in these cases. However, the differences between the types of anticoagulation, Low Molecular Weight Heparin (LMWH), Unfractionated Heparin (UFH), Dabigatran have not yet been well established, although there is a predilection for the use of LMWH. Also, thrombectomy is a therapeutic intervention option that should be evaluated, due to the risk of additional endothelial injury from the use of stent retrievers.

Conclusion: Although it has a relatively low incidence, CVT aggravates the condition and increases the risk of death for patients with COVID-19. Because of this, early diagnosis and evaluation of therapeutic options for CVT are essential for the development of clinical management.

Keywords: COVID-19, coronavirus, thrombosis, venous thrombosis, central nervous system, intracranial thrombosis
Volume II Issue 2 - 202 I

Carlos Alexandre Martins Zicarelli,' Jonathan Vinicius Martins, ${ }^{2}$ Wesley Vieira Doni, ${ }^{2}$ Rafael Rodrigues Pinheiro dos Santos, ${ }^{2}$ Ana Carla Mondek Rampazzo, ${ }^{2}$ Gabrielli Algazal Marin, ${ }^{2}$ Mariana Ramos do Nascimento, ${ }^{2}$ Igor Ruan de Araújo Caetano, ${ }^{2}$ Maria Letícia Nogueira, ${ }^{2}$ José Ângelo Favoreto Guarnieri, ${ }^{3}$ Victor Guilherme Batistela Pereira, ${ }^{3}$ Franciele Frazoli, ${ }^{3}$ Ivan Hattanda ${ }^{4}$

'Head of the Neurosurgery Residency at Evangelical Hospital of Londrina. Supervisor of the Medical Internship at Pontifical Catholic University of Paraná, PhD student in the Rehabilitation Science Program at the State University of Londrina/North Paraná University of Londrina, Brazil ${ }^{2}$ Medical Student at Pontifical Catholic University of Paraná, Brazil

${ }^{3}$ Medical Resident in Neurosurgery at the Evangelical Hospital of Londrina, Brazil

${ }^{4}$ Neurosurgeon at Evangelical Hospital of Londrina, Cancer Hospital of Londrina and Heart Hospital of Londrina, Brazil

Correspondence: Carlos Alexandre Martins Zicarelli, Head of the Neurosurgery Residency at Evangelical Hospital of Londrina, Av. Bandeirantes, 618 - Vila Ipiranga, Londrina - PR, 860I5-900, Londrina, Paraná, Brazil, Email carloszicarelli@gmail.com

Received: April 15, 2021 | Published: April 28, 2021
Abbreviations: SARS-CoV-2, severe acute respiratory syndrome Coronavirus 2; RNA, ribonucleic acid; COVID-19, Coronavirus Disease-19; IL-1, Interleukin-1 beta; IL-8, interleukin-8; IL-6, interleukin-6; ICU, intensive care unit; CVT, cerebral venous thrombosis; VTE, venous thromboembolism; ACE2, angiotensinconverting enzyme; vWF, von Willebrand factor; INF I, I interferon; TF, tissue factor; NETs, neutrophil extracellular traps; HIF 1, hypoxiainducible factor 1; CNS, central nervous system; Angio-CT, angiocomputed tomography; MRI, magnetic resonance imaging; LMWH, low molecular weight heparin; UFH, unfractionated heparin; aPTT, activated partial thromboplastin time'; rt-PA, recombinant tissue plasminogen activator; EVD, external ventricular drainage; TICI 3FPE, thrombolysis in cerebral infarction with first pass effect; MRI, Magnetic resonance imaging; RMv, magnetic resonance imaging with venography; N/R, not reported; OB, obesity; DM2, diabetis melitus type 2; HBP, high blood pressure; W/A, without antecedents; $\mathrm{BCa}$, breast cancer; Hach, headache; $\mathrm{CTv}$, computer tomography with venography; $\mathrm{BV}$, blurred vision

\section{Introduction}

Coronavirus disease-19 (COVID-19) was first observed in December 2019, in the Chinese city of Wuhan. ${ }^{1}$ Since that time, the infection caused by Severe Acute Respiratory Syndrome - Coronavirus 2 (SARS-CoV-2) has taken on global proportions and generated over 135 million cases worldwide. ${ }^{2}$ The SARS-CoV-2 is a single-stranded ribonucleic acid (RNA) virus with the largest RNA genome already defined and presents three viral proteins in the virion envelope: envelope protein $(\mathrm{E})$, membrane protein $(\mathrm{M})$ and spike protein $(\mathrm{S})$, the latter being responsible for determining cell tropism and the pathogenesis of the disease. ${ }^{3,4}$ Despite being well-established that patients suffering from COVID-19 present with symptoms such as dry cough, fever, lack of air, throat pain, headache, fatigue and diarrhea, ${ }^{5}$ there have been reports of multisystemic manifestations including thromboembolic and neurological complications. ${ }^{6}$ In these cases, the predisposition to developing venous and/or arterial thrombosis after infection by the virus, seems to be related to the inflammatory picture, endothelial dysfunction, plaque activation and blood stasis. ${ }^{7}$ A number of studies have suggested that the infection might promote the process known as pyroptosis (pro-inflammatory programmed cell death), resulting in severe endothelial dysfunction, concomitant with an increase in interleukin-1 beta (IL-1) and interleukin-8 (IL-8), resulting in a state of hypercoagulability. ${ }^{7}$

According to study by Matteo Nicolas, ${ }^{8}$ in a sample of 5,487 patients with severe symptoms and 9,670 with moderate symptoms, 
an extension of the prothrombin time, increase in D-dimers and high levels of fibrinogen were identified, simultaneously with platelet reduction, corroborating the thrombotic changes associated with the infection. ${ }^{8}$ Moreover, it was found that the high levels of D-dimer are linked to an increase in the rate of vascular complications. ${ }^{9}$

In one Italian university hospital, thrombotic events occurred in $7.7 \%$ of closed cases ${ }_{10}^{10}$ while other studies found that, even with prophylaxis, the incidence of thrombotic complications with COVID-19 patients in ICU, was 31\%. ${ }^{11}$ Given this scenario, cerebral venous thrombosis (CVT) was reportedly associated with COVID-19. ${ }^{12-16}$ In view of the copious articles published about changes caused by SARS-CoV-2 and by the growing prevalence of thrombotic events simultaneously with the viral condition, it has become extremely important to evaluate the elements which constitute CVT in this scenario. ${ }^{10-16}$

The aim of this study was to assess the impact of infection by SARS-CoV-2 on Cerebral Venous Thrombosis, investigating the topics: epidemiology, physiopathology, clinical picture, diagnosis, treatment and the outcome of the disease.

\section{Material and methods}

For the review of the literature, a search of the PubMed and Embase databases was carried out using the search terms "COVID-19", "SARSCoV-2", "Venous thromboembolism","Thrombosis","Cerebral Venous Thrombosis", "Intracranial Sinus Thrombosis" and "Cranial Sinus Thrombosis". Only articles in the English language were selected. Inclusion criteria comprised studies relating to the physiopathology of the venous thromboembolism, epidemiology, clinical picture, diagnosis, treatment and outcome of cerebral venous thrombosis in patients with COVID-19.

Moreover, in order to gather various clinical data concerning cerebral venous thrombosis and infection with SARS-CoV-2, the patient data were summarized into tables based on articles containing cases reported in literature from articles in the PubMed database, using the search terms "COVID-19" and "Cerebral Venous Thrombosis".

\section{Epidemiology}

Previous meta-analyses have reported an association between COVID-19 and high rates of venous thromboembolic complications. ${ }^{17,18}$ Generally speaking, CVT is a rare form of venous thromboembolism (VTE) with an annual incidence of between 3 and 4 million adults and approximately seven per million children. ${ }^{19}$ Precise data concerning the impact of the SARS-CoV-2 pandemic on the incidence of the pathology are not available, however, Favas et al. ${ }^{20}$ estimate that the incidence of CVT in patients with COVID-19 is approximately $0.3 \%$, indicating that recent epidemiological studies may demonstrate a real growth in the incidence of CVT. ${ }^{20}$

In agreement with the study of Favas et al. (2020), Tommaso Baldini et al. (2021) report that rates of CVT associated with SARSCoV-2 have varied. In hospitalized patients it was around 0.02 to $1 \%$, and $0.06 \%$ for those COVID-19 patients referred for neurological assessment. $^{21}$

Both of these conditions, CVT and infection with COVID-19, occur independently in the young population, however, CVT is also related to additional risk factors such as trauma, use of oral contraceptives, malignant neoplasms, dehydration and a state of hypercoagulability. ${ }^{22}$ Of the patients who presented with CVT while suffering from infection with the Coronavirus, it is suggested that there is a higher prevalence when there is a history of prior hypertension, diabetes and prior cerebrovascular disease.$^{23}$ The incidence of CVT associated with COVID-19 seems to be no different from CVT on its own, primarily affecting the female sex. ${ }^{24}$ However, some studies have shown that the rate of mortality is significantly higher for patients infected with the virus than for patients suffering from CVT resulting from other etiologies. $^{25,26}$

\section{Physiopathology}

Infection with SARS-CoV-2 and the correlation with thromboembolic events has not yet been fully explained. However, certain biological factors are associated with the development of thromboembolic events, including CVT. 17,18,21,27

SARS-CoV-2 is a single-stranded RNA virus that binds to the target cell by way of the S-protein, which is responsible for the binding to the angiotensin-converting enzyme (ACE2) receptor and for the fusion of the virus in the host cell membrane ${ }^{28,29}$ The interaction between this protein and ACE2 produces a deregulation in the receptor, with hyperproduction of angiotensin II, which can cause generalized endothelial damage. ${ }^{30-32}$ In addition, it has been reported that, with endothelial damage caused by the virus, there is more than three times the increased expression of the active von Willebrand factor ( $\mathrm{vWF})$, which is also a predisposing factor for thromboembolic events. 33

Moreover, infection with SARS-Cov-2 may cause a state of excessive inflammation which, consequently, produces a prothrombotic condition. ${ }^{7,15,34}$ Hyperactivation of the immune system occurs due to the viral expression of proteins that inhibit the synthesis of type I interferon (INF I), which causes a delayed antiviral immune response and facilitates replication of the SARS-Cov-2.35 This causes the activation of monocytes and neutrophils that produce high rates of proinflammatory cytokines (e.g. IL-1, IL-6 and IL-8), culminating in hyperinflammation and in a "cytokine storm". ${ }^{21}$ These proinflammatory cytokines suppress the anticoagulating pathways through the reduction of the tissue factor pathway inhibitor, release of ultra-large $\mathrm{VWF}$ and the induction of tissue factor (TF) expression. ${ }^{36}$ Subsequently, vWF promotes the adhesion of monocytes, neutrophils, platelets and microparticles in the activated endothelium. This causes the release of Neutrophil Extracellular Traps (NETs), the activation of the coagulation pathway via TF/FVIIa and platelet activation..$^{30,34,36-38}$ Lastly, several studies have suggested that infection with SARSCoV-2 contributes to an increase in the levels of D-dimer, fibrinogen, anticardiolipin antibodies and fibrinogen degradation product. . $^{30,37,38}$ All of these processes create an imbalance between the procoagulant and anticoagulant systems, leading to a state of hypercoagulability. ${ }^{36}$

In addition to the physiopathological factors, the clinical condition and the hospitalization of patients with COVID-19 in critical condition could promote the formation of thrombi ${ }^{36}$ Immobilization and prone positioning (used for diverse patients with the infection), reduce venous return, contributing to creating a condition of blood stasis. ${ }^{32}$ Moreover, hyperthermia contributes to the activation of the platelets and the coagulation pathways, associated with the hypovolemic state, due to the loss of gastrointestinal liquid and, in addition, there is an increase in blood viscosity. ${ }^{34,36}$ For patients with hypoxemia, there may be vasoconstriction, culminating in reduced blood flow and the induction of the expression of hypoxia-inducible factor 1 (HIF 1). ${ }^{34,36}$

It is known that SARS-CoV-2 has neurotropic potential. Its dissemination into the Central Nervous System (CNS) occurs by means of two pathways: hematogenic pathway- where the virus affects endothelial cells of the blood-brain barrier or afflicts the CNS by means of infected neutrophils; and/or the retrograde neuronal 
pathway - where the arrival of the virus occurs through the axonal transport of the peripheral nerves, such as the olfactory nerve. This neurotropism may provoke neurological disorders like meningitis/ encephalitis. ${ }^{39}$ It is suspected that this direct invasion of the CNS may contribute to the pathogenesis of CVT, although the mechanism of how this takes place is still unclear. ${ }^{21}$

\section{Clinical and radiological features}

Generally speaking, the principal clinical manifestations associated with CVT are: signs of intracranial hypertension, headache $(95 \%)$, blurred vision $(15 \%)$, papilledema $(30 \%)$, reduced consciousness (19\%), focal neurological deficits $(30 \%)$ and convulsion $(19 \%){ }^{40}$

By evaluating a group of eight patients who presented with CVT at the same time as being diagnosed with COVID-19, it was found that the majority of patients present with symptoms not specifically related to the virus, and neurological symptoms such as syncope and focal neurological deficit were identified on a smaller scale ${ }^{24}$. In this group, the onset of CVT-related symptoms (hemiparesis, weakness, aphasia, altered vision) occurred, on average, three days after the initial COVID-19 diagnosis, being radiologically diagnosed between six and 16 days after the onset of the condition. ${ }^{24}$ Initial symptoms of CVT may include an increase in intracranial pressure, progressive headache, sight problems, papilledema, focal neurological deficit, loss of consciousness and convulsions. However, progressive headache appears to be the most common symptom in patients with CVT, concomitant with the coronavirus. ${ }^{41}$

With regard to the signs and symptoms developed by patients with COVID-19 who presented with CVT, the following conditions were reported: headache ( 31 to $49 \%$ ), focal neurological deficit (31 to $32 \%$ ), fever $(29 \%)$, reduced level of consciousness (24 to $31 \%$ ), gastrointestinal tract symptoms $(21 \%)$, coughs (19\%), dyspnea $(12 \%)$. In addition, the average time between the start of COVID-19 symptoms and the CVT diagnosis was between seven and 11 days. ${ }^{13,42}$ The study presented by Baldini et al (2021) demonstrates that changes in mental state occur in around $60 \%$ and epileptic convulsion in $28 \%$ of cases of CVT in patients with COVID-19. ${ }^{21}$

Lastly, common symptoms of viral infection with SARS-CoV-2, like headache, can delay the diagnosis of CVT to the extent that the neurological symptoms may be aggravated ${ }^{15}$. Several authors note that the difference between viral headache and CVT-associated headache is based on the progressive worsening of pain when associated with CVT. $^{42}$

In relation to the location of the thrombi, imaging data suggest that thrombosis in multiple veins is more common than an event in a single vein. Moreover, the transverse sinus is the most affected location $(65 \%)$, followed by the sigmoid sinus (47\%), superior sagittal sinus (44\%) and straight sinus (21\%). Thrombosis could also occur in the deep venous system $(37 \%)$ and in the cortical venous system $(21 \%){ }^{21}$

\section{Diagnosis}

The diagnosis of CVT is made on the basis of clinical and laboratory suspicions, confirmed by way of imaging examinations. ${ }^{21}$ According to the study by Baldini et al (2021), the laboratory data in patients with CVT and COVID-19 presented fibrinogen abnormalities, an increase in D-dimer and C-reactive Protein. In addition, the most frequently employed imaging method for the diagnosis was Angio-Computed Tomography (Angio-CT), although Magnetic Resonance Imaging (MRI) may also be used. ${ }^{13}$
In the context of CVT, rapid diagnosis and treatment is vital given the severity of the condition. In this regard, patients with high levels of D-dimer and fibrinogen, with headache, convulsion and/or focal symptoms, should be investigated to eliminate cerebral venous thrombosis. ${ }^{43}$

\section{Treatment}

\section{Anticoagulants}

The basis for the treatment of CVT is anticoagulant therapy, the aim of which is to recanalize the obstructed vessel, avoid the propagation of the clot, prevent pulmonary embolism and treat the prothrombotic condition. ${ }^{43,44}$ Although there exist few studies concerning CVT therapy in connection with COVID-19, the thromboprophylaxis recommendations are general and the drug of choice may be either unfractionated heparin (UFH), or low molecular weight heparin (LMWH) ${ }^{44}$ The use of anticoagulants produces a significant reduction in mortality, particularly in patients who present with high levels of D-dimer $(>3.0 \mu \mathrm{g} / \mathrm{mL}) .{ }^{45} \mathrm{LMWH}$ seems to favor a reduction in thrombotic complications when compared to UFH, in that it is safer, more effective, and has a more predictable pharmacokinetic profile. ${ }^{45}$

For those patients with a diagnosis of acute CVT, in a randomized clinical trial comprising 66 individuals with CVT, a statistically significant reduction in hospital mortality was identified for patients using LMWH in comparison with patients using UFH $(0 \%$ versus $19 \%$ ). As well as the reduction in mortality, the group that used LMWH recovered better than the group using UFH, however there was no statistical evidence to support this comparison. ${ }^{38}$

The use of heparins is based on evidence that suggests the medication is capable of binding to the S-proteins of the viral envelope, helping to reduce IL-6, which has a negative impact on immune activation, reducing the systemic inflammatory process and, consequently, the physiopathological aspects that promote the development of CVT. ${ }^{13}$

In the study conducted by Tu et al. (2020), the survival rate using anticoagulation was $60 \%$, suggesting that the treatment employed for CVT of different etiology, is also effective for COVID-19-related CVT. ${ }^{13}$ This strengthens the possibility of early anticoagulation as a strategy for reducing CVT-associated mortality. ${ }^{13}$ In a sample of 14 patients treated with anticoagulants, five died, of which three were deemed to be in critical condition and two in the moderate stage, which leads to the perception that the degree of viral infection may or may not impair the patient's neurological status, generating a worse prognosis regardless of the type of therapeutic approach. ${ }^{21}$

In a sample of 38 patients with CVT, where anticoagulants were being used on 37 adult patients and aspirin for one pediatric patient, Baldini et al. ${ }^{21}$ observed a mortality rate of $40 \%(14 / 35) .{ }^{21}$ Moreover, seven patients treated with anticoagulants needed surgery even while undergoing drug treatment. Six of these patients ended up dying. ${ }^{21}$ In this study, the pediatric patient on whom the strategy of platelet antiaggregation with aspirin was carried out, did not require subsequent surgery and achieved partial recovery from her condition. ${ }^{45}$

Several authors have suggested that, despite LMWH presenting statistical data favorable to the treatment of CVT, the use of UFH should be considered for patients in a critical condition, who may require subsequent surgery, due to the activated partial thromboplastin time (aPTT) returning to normal levels one hour after the completion of the drug infusion. ${ }^{46}$ 
There is precious little data in the literature concerning CVT and the use of the new oral anticoagulants. Pang et al ${ }^{46}$ demonstrated satisfactory results with the use of dabigatran in just one patient, in whom the number of platelets, D-dimer, thromboplastin time (aPTT) remained unaltered and with no evidence of elevated inflammatory markers. ${ }^{46}$ This patient recovered fully from the CVT condition..$^{27,47}$ Two other studies demonstrated safety with the use of dabigatran but, due to the sample size, there was no consensus about the superiority of this drug in patients infected with SARS-CoV-2. ${ }^{48,49}$

Studies have shown a significant reduction in mortality in patients treated with anticoagulation, irrespective of the choice between UFH and HBPM, mainly in individuals with very high levels of D-dimer. ${ }^{48}$ Preventive anticoagulation continues to be recommended for patients with severe infection..$^{48}$ The use of other medication, such as recombinant tissue plasminogen activator (rt-PA) was associated with a temporary clinical improvement, but did not interfere with the mortality of patients with COVID-19-related CVT. ${ }^{12}$

\section{Surgery}

The use of thrombectomy is advocated to treat patients with severe CVT. ${ }^{12}$ The study by Cavalcanti et al. (2020) showed one patient, with a positive result for SARS-CoV-2 and CVT, subjected to thrombectomy following complications. ${ }^{21}$ Despite the fact that the patient ended up dying due to a worsening of the respiratory condition, it was reported that the superficial venous system showed significant improvement. ${ }^{50}$

In some cases, surgery has been employed ancillary to treatment with medication. In the study by Baldini et al. (2021), mortality resulting from thrombectomy was approximately $85 \%(6 / 7) .{ }^{50}$

Kananeh et al. (2020), in a sequence of four cases subjected to surgery, three of which were arterial ischemic stroke and one was CVT, three patients ended up dying, including the patient with the diagnosis of CVT. In this case, thrombectomy was not carried out on the patient with CVT, opting instead for external ventricular drainage (EVD), hypertonic therapy and anticoagulation with heparin ${ }^{7}$. On the other hand, a better evolution was found in the individual who underwent the thrombectomy, in combination with rt-PA and aspirin as secondary prevention. ${ }^{51}$

Although the physiopathology has not been well defined, it is known that VTE in patients with COVID-19 occurs via endothelial damage resulting from the inflammatory process. ${ }^{52}$ In this regard, it is suggested that thrombectomy using stent retrievers is associated with a risk of repeat thrombosis due to the exacerbated endothelial inflammatory response. ${ }^{53}$ So, in addition to the choice of surgery, COVID-19-related CVT requires an evaluation of the different forms of thrombectomy, due to differences in the efficacy of each technique. ${ }^{54}$ The total reopening of the vessel, according to the scale known as Thrombolysis In Cerebral Infarction with First Pass Effect (TICI 3 - FPE), is the standard thrombectomy protocol, associated with low mortality $(16.3 \%)$ and significant beneficial results have been observed in patient evolution. ${ }^{54}$ In a study conducted on patients infected with coronavirus, and with large-vessel CVT, none of the evaluated patients underwent complete reopening of the vessel after the first pass (TICI 3 FPE), suggesting that removal via thrombectomy in patients infected with the virus is more difficult than in patients with CVT but without COVID-19., $21,55,56$

\section{Outcome}

In the literature, there are reports of high mortality associated with CVT, ranging from 40 to $75 \%$ of cases. ${ }^{56,57}$ Studies still need to be conducted to help define risk and prognosis, however immediate treatment of the patient can contribute towards a positive outcome, while elevated levels of D-dimer indicate a more critical prognosis. ${ }^{55}$ In addition, there seems to be no direct connection between the severity of respiratory symptoms and CVT-related mortality. ${ }^{13,38,48,56,58}$

There is a consensus over the prescription of anticoagulants and their effect on the rates of patient mortality and recovery. ${ }^{7,21,23,46,53}$ Moreover, the difference in the patient's evolution appears to be subtle when compared to surgery and the use of anticoagulants, such that the outcome of death and worse prognoses are linked to high systemic inflammation indices. ${ }^{20}$

\section{Summary of the data in Table I}

In our review were include 28 articles, including a total of 39 cases of patients infected with CVT associated with COVID 19. This analysis contains the following data: age, gender, previous comorbidities / relevant factors, time between symptoms of COVID-19 and CVT, NIHSS, clinical manifestations, MRI findings, computed tomography / magnetic resonance findings with venography, treatment and prognosis. The mean age was 41,64 (the exact age of two pacientes has not been report, so they were not considered in the calculation), however was a wide age variation among the patients $(\sigma=18,67)$. The gender distribution was $59 \%$ men $(23 / 39)$. The time between symptons of COVID-19 and the appearance of CVT varied. But, in $43,6 \%$ of the cases (17/39), the symptoms of COVID-19 and CVT appeared at the same time, while in one other case CVT appeared 37 days after COVID 19 symptoms. There was also a case which CVT manifested four months after infection with SARS-CoV-2, she was a womam who already had history of previous bleeding, in addition to other thrombocytic diseases.

The NIHSS (National Institute of Health Stroke Scale score) has been reported seven times. The mean result was 6,4 and three patients had NIHSS greater than 4 . The neurological and systemic symptoms were: headache $59 \%(23 / 39)$, fever $28,2 \%$ (11/39), weakness $20,5 \%$ (8/39), convulsion $15,4 \%(6 / 39)$, loss of consciousness $15,4 \%(6 / 39)$, aphasia $12,8 \%(5 / 39)$, blurred vision $10,2 \%(4 / 39)$, confusion $10,2 \%$ (4/39), dysarthria 7,7\% (3/39), hemiparesis 7,7\% (3/39), vomit 7,7\% $(3 / 39)$, lethargy $5,1 \%(2 / 39)$, numbness $5,1 \%(2 / 39)$, hemiplegia $5,1 \%(2 / 39)$, imbalance $5,1 \%(2 / 39)$, astenia $5,1 \%(2 / 39)$, epileptic attack 5,1\% (2/39), tingling 5,1\% (2/39), agitation 5,1\% (2/39), body pain $2,56 \%(1 / 39)$, change in mental status $2,56 \%(1 / 39)$, executive dysfunction $2,56 \%(1 / 39)$, dyspraxia $2,56 \%(1 / 39)$, anosmia $2,56 \%$ (1/39), absence of stimulus to pain 2,56\% (1/39), chills $2,56 \%(1 / 39)$, fatigue $2,56 \%(1 / 39)$, delirium $2,56 \%(1 / 39)$, bone pain $2,56 \%(1 / 39)$, diarrhea $2,56 \%(1 / 39)$, papilledema $2,56 \%(1 / 39)$, dysphasia $2,56 \%$ $(1 / 39)$, disorientation $2,56 \%(1 / 39)$ and drowsiness $2,56 \%$ (1/39). It is important to note that many studies did not report systemic symptoms of COVID 19, which made it difficult to analyze these data.

The most altered laboratory exam was the D-dimer. In the 39 cases the d-dimer was reported in $71,8 \%(28 / 39)$ of the patients and was elevated in $85,7 \%(24 / 28)$ of reported cases. Fibrinogen was abnormally elevated in $50 \%(10 / 19)$ of the 19 cases that reported.

The mostly used anticoagulant therapy was the heparins: enoxaparin $36 \%(13 / 36)$, low molecular weight heparin $28 \%(10 / 36)$, heparin $19 \%(7 / 36$; undifferentiated in the case report if was used LMWH or UFH), and unfractionated heparin 14\% (5/36). Other medications used were: dabigatran $8 \%(3 / 36)$, apixaban $6 \%(2 / 36)$, rivaroxaban $6 \%(2 / 36)$, warfarin $3 \%(1 / 36)$, edoxaban $3 \%(1 / 36)$ and tPA $3 \%(1 / 36)$. Surgical treatment was utilized in eight patients: decompressive craniectomy $8 \%(3 / 36)$, thrombectomy $3 \%(1 / 36)$, and external ventricular drain insertion $3 \%(1 / 36)$. Three cases had no reported the treatment. 
Table I Literature review of case reports and case series of Cerebral Venous Thrombosis in patients with COVID I9

\begin{tabular}{|c|c|c|c|c|c|c|c|c|c|c|}
\hline Author & $\begin{array}{l}\text { Dakay et } \\
\text { al. - Patient } \\
\text { I }^{15}\end{array}$ & $\begin{array}{l}\text { Dakay et al. - } \\
\text { Patient } 2^{15}\end{array}$ & $\begin{array}{l}\text { Cavalcanti et } \\
\text { al. - Case } I^{12}\end{array}$ & $\begin{array}{l}\text { Cavalcanti et } \\
\text { al. - Case } 2^{12}\end{array}$ & $\begin{array}{l}\text { Cavalcanti } \\
\text { et al. - Case } \\
3^{12}\end{array}$ & $\begin{array}{l}\text { Hughes et } \\
\text { al. }{ }^{16}\end{array}$ & Garaci et al..$^{63}$ & Klein et al. ${ }^{38}$ & $\begin{array}{l}\text { Sugiyama et } \\
\text { al. }{ }^{41}\end{array}$ & $\begin{array}{l}\text { Hemasian and } \\
\text { Ansari }^{60}\end{array}$ \\
\hline Age & 17 & 72 & 38 & 41 & 23 & 59 & 44 & 29 & 56 & 65 \\
\hline Sex & M & $\mathrm{F}$ & $M$ & $\mathrm{~F}$ & $M$ & M & $\mathrm{F}$ & $\mathrm{F}$ & M & M \\
\hline $\begin{array}{l}\text { Previous } \\
\text { comorbidities } \\
\text { I relevant } \\
\text { factors }\end{array}$ & $\mathrm{OB}$ & $\mathrm{BCa}$ & $\begin{array}{l}\text { Autistic } \\
\text { spectrum }\end{array}$ & $\begin{array}{l}\text { Use of } \\
\text { estrogen- } \\
\text { based oral } \\
\text { contraceptives }\end{array}$ & W/A & $\begin{array}{l}\text { DM2 and } \\
\text { HBP }\end{array}$ & W/A & W/A & W/A & W/A \\
\hline $\begin{array}{l}\text { Time } \\
\text { between } \\
\text { symptoms of } \\
\text { COVID-19 } \\
\text { and } \\
\text { symptoms of } \\
\text { CVT }\end{array}$ & $\begin{array}{l}\text { At the same } \\
\text { time }\end{array}$ & Three days & $\begin{array}{l}\text { At the same } \\
\text { time }\end{array}$ & $\begin{array}{l}\text { Short period } \\
\text { of time }\end{array}$ & One week & $\begin{array}{l}\text { At the same } \\
\text { time }\end{array}$ & Two weeks & One week & Twelve days & At the same time \\
\hline NIHSS & 0 & 1 & 14 & 16 & $N / R$ & 10 & $N / R$ & $N / R$ & $N / R$ & $N / R$ \\
\hline $\begin{array}{l}\text { Clinical } \\
\text { condition }\end{array}$ & $\begin{array}{l}\text { Headache, } \\
\text { BV }\end{array}$ & $\begin{array}{l}\text { Dysarthria, } \\
\text { weakness in } \\
\text { the left hand } \\
\text { and dyspnoea }\end{array}$ & $\begin{array}{l}\text { Headache } \\
\text { for } 7 \text { days } \\
\text { and change in } \\
\text { mental status } \\
\text { in the last } 2 \\
\text { days }\end{array}$ & $\begin{array}{l}\text { Confusion and } \\
\text { aphasia }\end{array}$ & $\begin{array}{l}\text { Headache, } \\
\text { body aches, } \\
\text { fever, dry } \\
\text { cough and } \\
\text { lethargy. }\end{array}$ & $\begin{array}{l}\text { Persistent } \\
\text { high-intensity } \\
\text { Headache, } \\
\text { fever and } \\
\text { hypertension }\end{array}$ & $\begin{array}{l}\text { Progressive } \\
\text { dyspnea, } \\
\text { Headache, } \\
\text { mental } \\
\text { confusion, } \\
\text { aphasia and } \\
\text { hemiparesis on } \\
\text { the right side. }\end{array}$ & $\begin{array}{l}\text { Headache, } \\
\text { agitation, aphasia, } \\
\text { moderate } \\
\text { paralysis of the } \\
\text { right face and } \\
\text { convulsion. }\end{array}$ & $\begin{array}{l}\text { Severe } \\
\text { Headache and } \\
\text { vomiting. }\end{array}$ & $\begin{array}{l}\text { Convulsion and, } \\
\text { after hospital } \\
\text { admission, } \\
\text { drowsiness. }\end{array}$ \\
\hline $\begin{array}{l}\text { Laboratory } \\
\text { findings } * *\end{array}$ & $\begin{array}{l}\text { APTT = } \\
25.7 \mathrm{sTP} \\
=11.3 \mathrm{~s} \\
\text { INR }=1.06 \\
\text { Fibrinogen }= \\
355 \mathrm{mg} / \mathrm{dL}\end{array}$ & $\begin{array}{l}\text { APTT }=33.5 \mathrm{~s} \\
T P=11.7 \mathrm{~s} \\
I N R=1.10 \\
\text { Fibrinogen }= \\
509 \mathrm{mg} / \mathrm{dL} \\
\text { Prot. C react. } \\
=2.8 \mathrm{mg} / \mathrm{dL}\end{array}$ & N/R. & N/R. & $\begin{array}{l}\text { D-dimer = } \\
2032 \mathrm{ng} / \mathrm{mL}\end{array}$ & $\begin{array}{l}\text { TPTP }=19.7 \mathrm{~s} \\
\text { TP }=11.2 \mathrm{~s} \\
\text { Prot. } C \text { react. } \\
=20 \mathrm{mg} / \mathrm{L} \\
\text { Fibrinogen }= \\
4.9 \mathrm{~g} / \mathrm{L}\end{array}$ & $\begin{array}{l}\text { D-dimer = } \\
5975 \mathrm{ng} / \mathrm{mL} \\
\text { Platelets }= \\
42,000 / \mu \mathrm{L} \\
\mathrm{CKMB}=6.9 \\
\mathrm{ng} / \mathrm{mL}\end{array}$ & $\begin{array}{l}\text { APTT }=28.7 \mathrm{~s} \\
\text { Prot. C react. } \\
=37 \mathrm{mg} / \mathrm{L} \\
\text { Fibrinogen }=4.9 \\
\text { g } / \mathrm{L} \text { D-dimer }= \\
2876 \mathrm{ng} / \mathrm{L}\end{array}$ & $\begin{array}{l}\text { D-dimer = } \\
10.3 \mu \mathrm{g} / \mathrm{mL}\end{array}$ & $N / R$ \\
\hline MRI findings & $\begin{array}{l}\text { Thrombosis } \\
\text { of the dural } \\
\text { venous sinus } \\
\text { in the left } \\
\text { transverse } \\
\text { and sigmoid } \\
\text { sinuses } \\
\text { extending } \\
\text { to the left } \\
\text { internal } \\
\text { jugular and } \\
\text { straight } \\
\text { sinuses; } \\
\text { possible } \\
\text { thrombus } \\
\text { in the left } \\
\text { Labbe's vein. }\end{array}$ & $\begin{array}{l}\text { Without } \\
\text { changes. }\end{array}$ & N/R. & N/R. & $\begin{array}{l}\text { Pathologically } \\
\text { reduced } \\
\text { diffusion } \\
\text { throughout } \\
\text { the } \\
\text { subcortical } \\
\text { area of deep } \\
\text { white matter. }\end{array}$ & N/R. & N/R. & $\begin{array}{l}\text { Hemorrhagic } \\
\text { infarction } \\
\text { in the left } \\
\text { temporoparietal } \\
\text { area, with } \\
\text { extinguishment } \\
\text { of the left lateral } \\
\text { ventricle and the } \\
\text { third ventricle } \\
\text { with a deviation } \\
\text { of } 4 \mathrm{~mm} \text { to the } \\
\text { right. }\end{array}$ & $\begin{array}{l}\text { Results } \\
\text { compatible } \\
\text { with TEC } \\
\text { at the } \\
\text { confluences } \\
\text { of the left } \\
\text { transverse } \\
\text { sinus. }\end{array}$ & $\begin{array}{l}\text { RMR demonstrates } \\
\text { thrombosis of the } \\
\text { right and transverse } \\
\text { sigmoid sinuses. }\end{array}$ \\
\hline $\begin{array}{l}\text { CT / RMv } \\
\text { findings * }\end{array}$ & $\begin{array}{l}\text { RMv - } \\
\text { Elongated } \\
\text { filling defect } \\
\text { at the } \\
\text { confluence } \\
\text { of the left } \\
\text { transverse } \\
\text { and sigmoid } \\
\text { sinuses and } \\
\text { the proximal } \\
\text { internal } \\
\text { jugular } \\
\text { vein. Partial } \\
\text { extension } \\
\text { of the right } \\
\text { transverse } \\
\text { and superior } \\
\text { sagittal } \\
\text { sinuses. Large } \\
\text { thrombus } \\
\text { in a straight } \\
\text { sinus and in } \\
\text { Labbe's left } \\
\text { vein. }\end{array}$ & $\begin{array}{l}\text { CT - Filling } \\
\text { defects in the } \\
\text { right sigmoid } \\
\text { sinus and } \\
\text { jugular bulb }\end{array}$ & $\begin{array}{l}\text { CT - } \\
\text { hyperdensity } \\
\text { in the straight } \\
\text { sinus, superior } \\
\text { distal sagittal } \\
\text { sinus and right } \\
\text { transverse } \\
\text { sinus. CTv } \\
\text { - almost } \\
\text { occlusive } \\
\text { thrombus } \\
\text { in the right } \\
\text { internal } \\
\text { cerebral vein. }\end{array}$ & $\begin{array}{l}\text { CT - venous } \\
\text { infarction } \\
\text { of the left } \\
\text { basal ganglia, } \\
\text { thalamus } \\
\text { and mesial } \\
\text { temporal lobe, } \\
\text { intraventricular } \\
\text { hemorrhage } \\
\text { and } \\
\text { obstructive } \\
\text { hydrocephalus. } \\
\text { CTv - } \\
\text { occlusion of } \\
\text { the internal } \\
\text { cerebral veins } \\
\text { with significant } \\
\text { enlargement } \\
\text { of the Galen } \\
\text { vein and distal } \\
\text { straight sinus. }\end{array}$ & $\begin{array}{l}\text { CT - irregular } \\
\text { areas of low } \\
\text { density in the } \\
\text { two cerebral } \\
\text { hemispheres, } \\
\text { with a focus } \\
\text { of subcortical } \\
\text { hemorrhage } \\
\text { in the left } \\
\text { occipito- } \\
\text { parietal } \\
\text { region. }\end{array}$ & $\begin{array}{l}\text { CT - } \\
\text { hyperdensity } \\
\text { in the } \\
\text { superior } \\
\text { sagittal } \\
\text { sinus, right } \\
\text { transverse, } \\
\text { sigmoid } \\
\text { sinus and } \\
\text { right upper } \\
\text { internal } \\
\text { jugular vein. } \\
\text { CTv - no } \\
\text { changes. } \\
\text { After } 4 \text { days, } \\
\text { CTv revealed } \\
\text { a filling } \\
\text { defect in the } \\
\text { right sigmoid } \\
\text { sinus and } \\
\text { transverse } \\
\text { sinus. }\end{array}$ & $\begin{array}{l}\text { CTv - filling } \\
\text { failure in the } \\
\text { Galen vein, } \\
\text { straight sinus } \\
\text { and torcular } \\
\text { herophilus due } \\
\text { to thrombosis } \\
\text { in the dural } \\
\text { sinus with poor } \\
\text { representation } \\
\text { of the left } \\
\text { internal } \\
\text { cerebral vein. }\end{array}$ & $\begin{array}{l}\mathrm{CT} \text { - } \\
\text { Hemorrhagic } \\
\text { venous } \\
\text { infarction } \\
\text { in the left } \\
\text { temporoparietal } \\
\text { area with edema } \\
\text { and venous } \\
\text { thrombosis in } \\
\text { the left distal } \\
\text { transverse sinus } \\
\text { and sigmoid } \\
\text { sinus. }\end{array}$ & $\begin{array}{l}\text { CT - Results } \\
\text { compatible } \\
\text { with TEC } \\
\text { at the } \\
\text { confluences } \\
\text { of the left } \\
\text { transverse } \\
\text { sinus. }\end{array}$ & $\begin{array}{l}\text { CT - hemorrhagic } \\
\text { infarction in the } \\
\text { temporal lobe. }\end{array}$ \\
\hline Treatment & Enoxaparin & $\begin{array}{l}\text { Anticoagulants } \\
\text { were not } \\
\text { administered } \\
\text { due to change } \\
\text { in treatment } \\
\text { strategy }\end{array}$ & $\begin{array}{l}\text { Enoxaparin } \\
70 \mathrm{mg} 2 \mathrm{x} / \\
\text { day, after } \\
\text { worsening, } \\
\text { thrombectomy } \\
\text { and } \\
\text { microcatheter } \\
\text { incision were } \\
\text { performed for } \\
\text { tPA infusion at } \\
\text { a rate of } 2 \mathrm{mg} \\
\text { / h. Lopinavir- } \\
\text { ritonavir was } \\
\text { inserted. }\end{array}$ & $\begin{array}{l}\text { Insertion of } \\
\text { an external } \\
\text { ventricular } \\
\text { drain and a } \\
\text { bolus heparin } \\
\text { infusion was } \\
\text { started. }\end{array}$ & $N / R$ & $\begin{array}{l}\text { After the } \\
\text { second exam } \\
\text { treated } \\
\text { with low } \\
\text { molecular } \\
\text { weight } \\
\text { heparin and } \\
\text { after high } \\
\text { apixaban } \\
\text { IOmg } 2 \times 1 \\
\text { day for } 7 \\
\text { days in the } \\
\text { reference } \\
\text { service. }\end{array}$ & $\begin{array}{l}\text { Tocalizumab } \\
\text { and low } \\
\text { molecular } \\
\text { weight heparin. }\end{array}$ & $\begin{array}{l}\text { Correction of } \\
\text { anemia with } \\
\text { two units of } \\
\text { red blood cells } \\
\text { and ferrous } \\
\text { sulfate } 325 \mathrm{mg} \\
\text { / day, after } \\
\text { stabilization } \\
\text { started } \\
\text { intravenous } \\
\text { heparin and, } \\
\text { subsequently, } \\
50 \mathrm{mg} \\
\text { subcutaneous } \\
\text { enoxaparin I2 } \\
\text { / I2h. }\end{array}$ & $\begin{array}{l}\text { Unfractionated } \\
\text { heparin was } \\
\text { administered } \\
\text { and replaced } \\
\text { by edoxaban } \\
\text { ( } 60 \mathrm{mg} / \text { day) } \\
\text { six days later. }\end{array}$ & $\begin{array}{l}\text { Therapy with } \\
\text { anticoagulant, } \\
\text { levetiracetam, } \\
\text { hydroxychloroquine } \\
\text { and amoxicillin + } \\
\text { acid. clavulanic. }\end{array}$ \\
\hline
\end{tabular}


Table Continued...

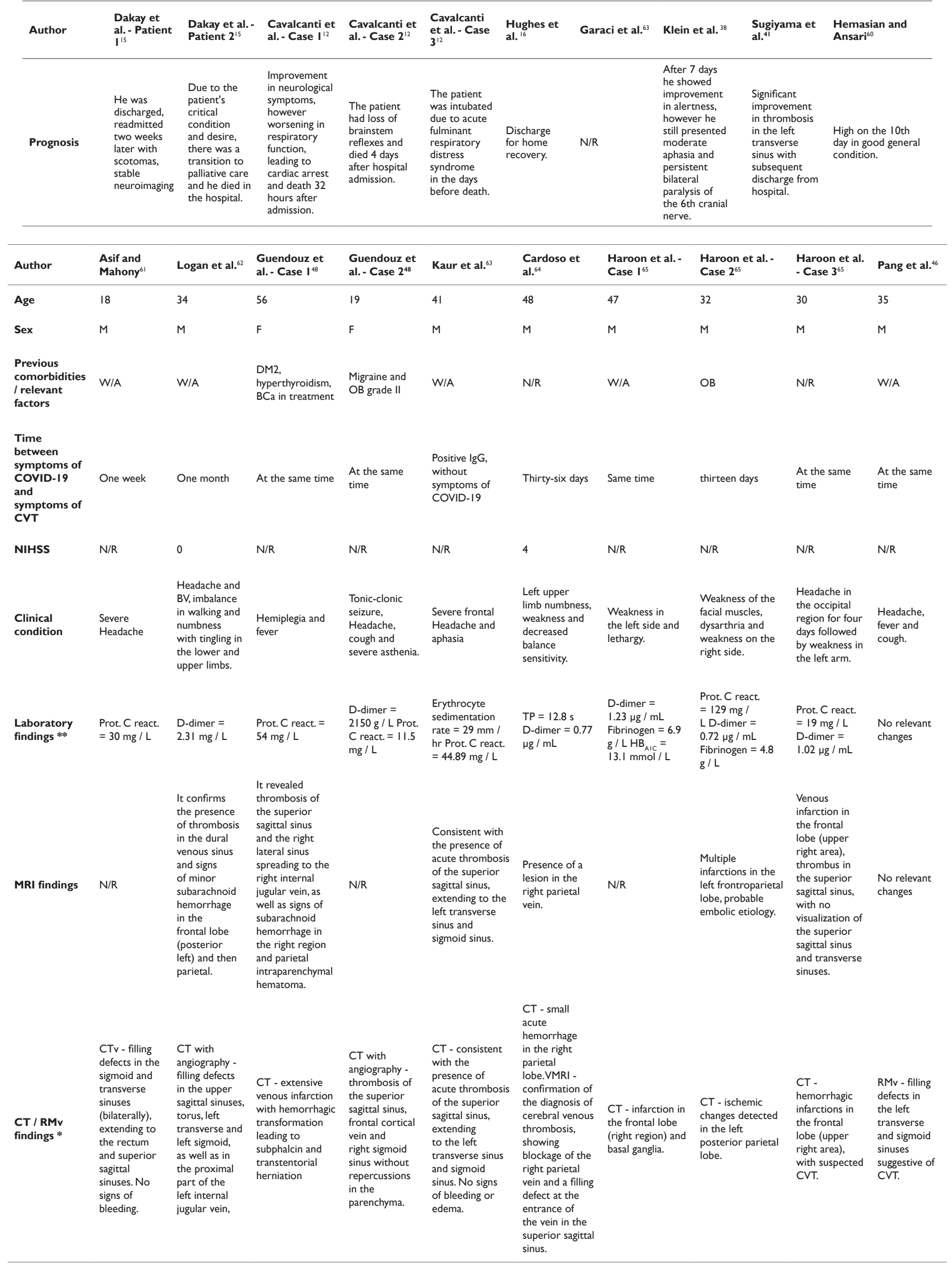

Citation: Zicarelli CAM, Martins JV, Doni WV, et al. Cerebral venous thrombosis and Covid 19: Literature review.J Neurol Stroke. 202 I; I (2):57-68. 
Table Continued.

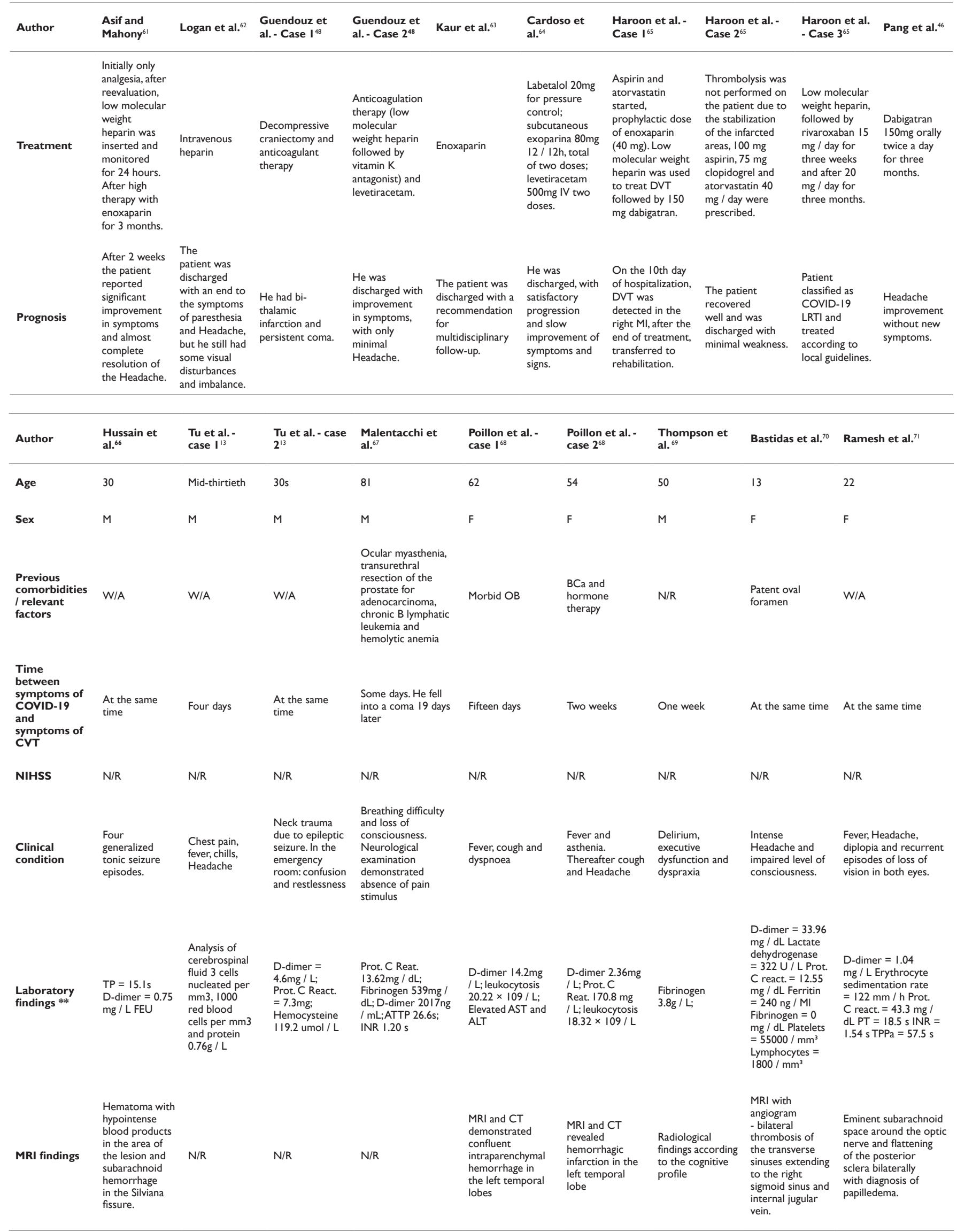


Table Continued..

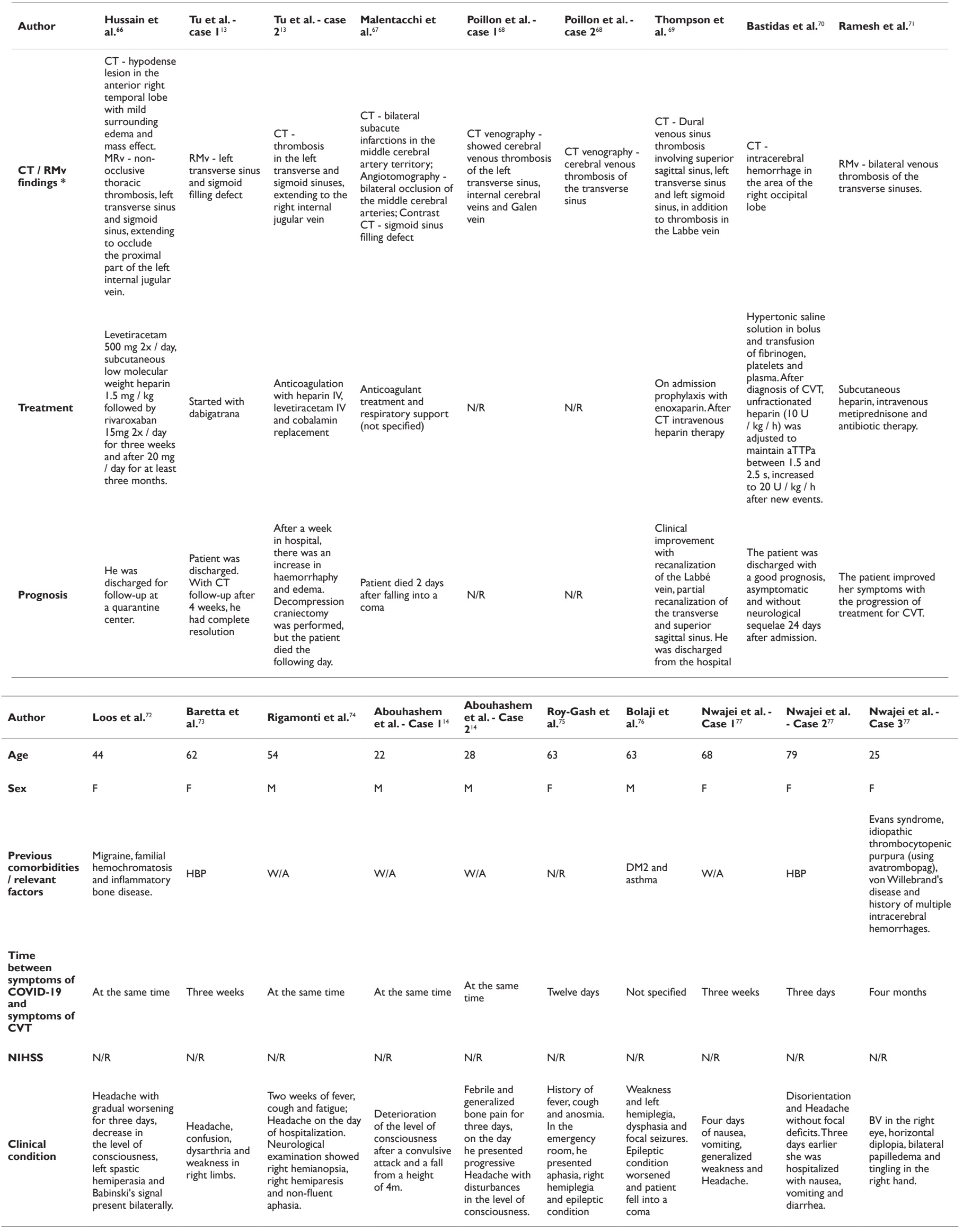


Table Continued...

\begin{tabular}{|c|c|c|c|c|c|c|c|c|c|c|}
\hline Author & Loos et al. ${ }^{72}$ & $\begin{array}{l}\text { Baretta et } \\
\text { al. }^{73}\end{array}$ & Rigamonti et al. ${ }^{74}$ & $\begin{array}{l}\text { Abouhashem } \\
\text { et al. - Case I }\end{array}$ & $\begin{array}{l}\text { Abouhashem } \\
\text { et al. - Case } \\
2^{14}\end{array}$ & $\begin{array}{l}\text { Roy-Gash et } \\
\text { al. }^{7^{5}}\end{array}$ & $\begin{array}{l}\text { Bolaji et } \\
\text { al. }^{76}\end{array}$ & $\begin{array}{l}\text { Nwajei et al. - } \\
\text { Case I }{ }^{77}\end{array}$ & $\begin{array}{l}\text { Nwajei et al. } \\
\text { - Case } 2^{77}\end{array}$ & $\begin{array}{l}\text { Nwajei et al. - } \\
\text { Case } 3^{77}\end{array}$ \\
\hline $\begin{array}{l}\text { Laboratory } \\
\text { findings ** }\end{array}$ & $\begin{array}{l}\text { D-dimer }=1.9 \\
\mu \mathrm{g} / \mathrm{mL} \text { Prot. C } \\
\text { react. }=19 \mathrm{mg} / \\
\mathrm{dL} \text { Anticardiolipin } \\
\mathrm{lgG}=45 \mathrm{GPL} \\
\mathrm{U} / \mathrm{mL}\end{array}$ & $\begin{array}{l}\text { D-dimer = } \\
2768 \mathrm{ng} / \mathrm{mL} \\
\text { Prot. C react. }= \\
19.45 \mathrm{mg} / \mathrm{dL}\end{array}$ & $\begin{array}{l}\text { D-dimer }=3000 \\
\mathrm{ng} / \mathrm{mL} \text { Prot. C } \\
\text { react. }=9.7 \mathrm{mg} / \mathrm{dL} \\
\text { Fibrinogen }=936 \\
\mathrm{mg} / \mathrm{dL}\end{array}$ & $N / R$ & $N / R$ & $\begin{array}{l}\text { Fibrinogen } 7.2 \\
\text { g/ L; ferritin } \\
\text { I } 427 \mu \mathrm{\mu g} / \mathrm{L}\end{array}$ & $\begin{array}{l}\text { D-dimer } \\
4.77 \mathrm{mg} / \mathrm{L} \\
\text { FEU; Prot. C } \\
\text { react. } 60 \mathrm{mg} \\
\text { / L; INR I.I; } \\
\text { Fibrinogen } \\
5.68 \mathrm{~g} / \mathrm{L}\end{array}$ & $\begin{array}{l}\text { D-dimer }= \\
67 / 4 \mathrm{ng} / \mathrm{dL} \\
\text { Ferritin }= \\
516 \mathrm{ng} / \mathrm{mL} \\
\text { Fibrinogen = } \\
507 \mathrm{mg} / \mathrm{dL} \\
\text { Prot. C react. } \\
=121.5 \mathrm{mg} / \\
\mathrm{L} \text { Erythrocyte } \\
\text { sedimentation } \\
\text { rate }=60 \mathrm{~mm} \\
/ \mathrm{h} \text { Lactate } \\
\text { dehydrogenase } \\
=348 \mathrm{U} / \mathrm{L}\end{array}$ & $\begin{array}{l}\text { Platelets = } \\
\mathrm{I} 13 \mathrm{~K} / \mathrm{UL} \\
\mathrm{D}-\text { dimer }= \\
8457 \mathrm{ng} / \mathrm{dL} \\
\text { Ferritin }=812 \\
\mathrm{ng} / \mathrm{mL} \text { Prot. } \\
\mathrm{C} \text { react. }=96.4 \\
\mathrm{mg} / \mathrm{L} \text { Lactate } \\
\text { dehydrogenase } \\
=434 \mathrm{U} / \mathrm{L}\end{array}$ & $\begin{array}{l}\text { White cell count } \\
=11.8 \mathrm{~K} / \mathrm{UL} \\
\mathrm{D}-\mathrm{dimer}=24 \mathrm{I} \\
\mathrm{ng} / \mathrm{dL}\end{array}$ \\
\hline
\end{tabular}

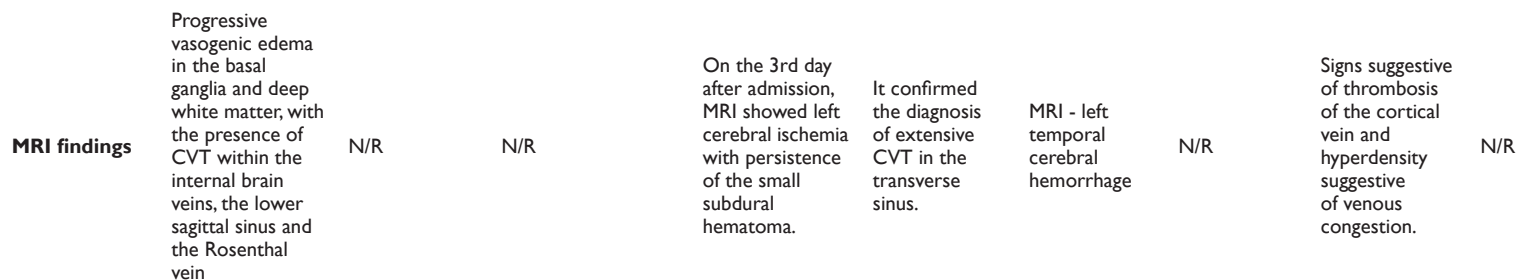

\begin{tabular}{|c|c|c|c|c|c|c|c|}
\hline $\begin{array}{l}\text { CT / RMv } \\
\text { findings * }\end{array}$ & $\begin{array}{l}\mathrm{CT} \text { - multiple } \\
\text { hypodense and } \\
\text { hyperdense areas, } \\
\text { involving the right } \\
\text { thalamus, left } \\
\text { caudate nucleus } \\
\text { and left pale } \\
\text { globe. }\end{array}$ & $\begin{array}{l}\text { CT - } \\
\text { hypodense } \\
\text { lesion in the } \\
\text { left parietal } \\
\text { area and } \\
\text { subarachnoidal } \\
\text { sulcal } \\
\text { hemorrhage } \\
\text { over the left } \\
\text { temporal lobe } \\
\text { CTv - CVT } \\
\text { involving } \\
\text { the right } \\
\text { transverse } \\
\text { sinus, right } \\
\text { jugular bulb, } \\
\text { superior } \\
\text { sagittal sinus, } \\
\text { straight sinus, } \\
\text { Galen vein and } \\
\text { both internal } \\
\text { cerebral veins. }\end{array}$ & $\begin{array}{l}\mathrm{CT} \text { - ischemic } \\
\text { hypodensity } \\
\text { involving the } \\
\text { left basal ganglia } \\
\text { and the thalamic } \\
\text { capsular region } \\
\text { associated with a } \\
\text { small hemorrhagic } \\
\text { hyperdensity close } \\
\text { to the caudate } \\
\text { nucleus, associated } \\
\text { with a mass effect } \\
\text { and change in the } \\
\text { structure of the } \\
\text { midline. CT with } \\
\text { angiography - } \\
\text { thrombosis involving } \\
\text { deep veins in the left } \\
\text { hemisphere. }\end{array}$ & $\begin{array}{l}\text { Initial CT } \\
\text { - small left } \\
\text { subduralcerebral } \\
\text { hematoma with } \\
\text { mild edema, } \\
\text { pneumocephalus } \\
\text { and skull } \\
\text { fracture. CT } \\
\text { after } 4 \text { days } \\
\text { - progressive } \\
\text { ischemia in the } \\
\text { left hemisphere } \\
\text { with change in } \\
\text { the midline. }\end{array}$ & $\begin{array}{l}\text { CT - } \\
\text { hyperdense } \\
\text { area in the } \\
\text { transverse } \\
\text { sinus and } \\
\text { positive } \\
\text { delta signal, } \\
\text { suspected } \\
\text { CVT. }\end{array}$ & $\begin{array}{l}\mathrm{CT} \text { - Cerebral } \\
\text { venous } \\
\text { thrombosis } \\
\text { confirmed }\end{array}$ & $\begin{array}{l}\mathrm{CT} \text { - venous } \\
\text { sinus } \\
\text { thrombosis } \\
\text { with bilateral } \\
\text { cortical } \\
\text { infarctions, in } \\
\text { addition to } \\
\text { acute cortiac } \\
\text { hemorrhage }\end{array}$ \\
\hline
\end{tabular}

CTv - filling defects in the superior posterior sagittal sinus, CTv - RMv - thrombosis torcula, straight curvilinear of the upper sinus, Galen's thrombus sagittal sinus and vein, inferior in the right transverse sinuses sagittal sinus, transverse bilaterally. cerebral veins and bilateral sinuses. inus.

\begin{tabular}{|c|c|c|c|}
\hline Treatment & $\begin{array}{l}\text { Low molecular } \\
\text { weight heparin } \\
\text { and mechanical } \\
\text { ventilation. }\end{array}$ & $\begin{array}{l}\text { Unfractionated } \\
\text { heparin } 5000 \\
U \text { in bolus, } \\
\text { followed by } \\
1000 \text { / } \\
\text { h adjusted } \\
\text { according } \\
\text { to aPTT; } \\
\text { followed by } \\
\text { subcutaneous } \\
\text { enoxaparin I } \\
\text { mg / kg every }\end{array}$ & $\begin{array}{l}\text { Supplementation } \\
\text { of oxygen, } \\
\text { hydroxychloroquine, } \\
\text { azithromycin and } \\
\text { lopinavir / ritonavir. } \\
\text { Afterwards, } \\
\text { enoxaparin } 100 \text { IU / } \\
\text { kg was started twice } \\
\text { a day and anti-edema } \\
\text { therapy. }\end{array}$ \\
\hline
\end{tabular}

Decompression
craniectomy,
two days after
the procedure
started
enoxaparin due
to the diagnosis
of CVT.

Treatme and, for epilepsy, lacosamide.
Subsequently, surgical evacuation epileptic of the received intracranial lorazepam hematoma and and decompressive phenytoin. craniectomy.

Treatment
with
HPBM and
levetiracetam.
After an
epileptic
attack, he
received
lorazepam
and
phenytoin.
intravenous (arin, then replaced by enoxaparin. the 2nd day, levetiracetam and lacosamide after EEG confirmed focal

\begin{tabular}{|c|c|c|c|}
\hline Prognosis & $\begin{array}{l}\text { On day } 45 \text {, after } \\
\text { neurological } \\
\text { improvement, he } \\
\text { was transferred } \\
\text { to a primary } \\
\text { referral hospital } \\
\text { for rehabilitation. } \\
\text { Six months later, } \\
\text { he had minimal } \\
\text { hemiparesis, } \\
\text { dysphagia and } \\
\text { multiple cognitive } \\
\text { deficits. }\end{array}$ & $\begin{array}{l}\text { Transfer } \\
\text { three weeks } \\
\text { later, with } \\
\text { switch from } \\
\text { anticoagulant } \\
\text { therapy to } \\
\text { warfarin and } \\
\text { discharge } \\
\text { three months } \\
\text { later with } \\
\text { functional } \\
\text { independence. }\end{array}$ & $\begin{array}{l}\text { The patient } \\
\text { worsened his } \\
\text { neurological } \\
\text { status } 4 \text { days after } \\
\text { admission, going into } \\
\text { a coma. The patient } \\
\text { was intubated } \\
\text { and underwent } \\
\text { decompression } \\
\text { surgery. There was } \\
\text { no improvement in } \\
\text { symptoms and the } \\
\text { patient died } 10 \text { days } \\
\text { later. }\end{array}$ \\
\hline
\end{tabular}

Transferred $\begin{array}{ll}\text { After } 14 \text { days } & \begin{array}{l}\text { to a } \\ \text { rehabilitation }\end{array} \\ \text { of admission } & \text { center, where }\end{array}$ to the center, wher emergency mobility room, he improved presented $\begin{array}{ll}\text { He was } \\ \text { discharged }\end{array}$ $\begin{array}{ll}\text { further discharged } & \\ \text { from the }\end{array}$ bleeding and training persistent center 3 thrombosis. weeks after He died 8 days the initial later. 8 days presenta at the
hospital. $\begin{array}{lll}\begin{array}{l}\text { Improvement } \\ \text { of mental }\end{array} & \begin{array}{l}\text { Improvement } \\ \text { of mental }\end{array} & \text { Patient was } \\ \text { and discharge } & \text { and discharge } & \text { discharged. } \\ \text { status. } & & \end{array}$

MRI, magnetic resonance imaging; RMv, magnetic resonance imaging with venography; N/R, not reported; OB, obesity; DM2, diabetes mellitus type 2; HBP, high blood pressure;W/A, without antecedents; BCa, breast cancer; CTv, computer tomography with Venography; BV, blurred Vision 
According to images exam results (computed tomography and magnetic resonance imaging) compiled in table 1, the most affected areas by CVT were: left transverse sinus 51\% (20/39), superior sagittal sinus 36\% (14/39), right transverse sinus 31\% (12/39), left sigmoid sinus 26\% (10/39), straight sinus 23\% (9/39), right sigmoid sinus $18 \%$ (7/39), Galen vein $13 \%$ (5/39), right internal cerebral vein $13 \%(5 / 39)$, left internal jugular vein 13\% (5/39), jugular bulb $8 \%$ $(3 / 39)$, inferior sagittal sinus 5\% (2/39), left Labbé vein 5\% (2/39), frontal cortical vein $3 \%(1 / 39)$, right parietal vein $3 \%(1 / 39)$, and Rosenthal vein 3\% (1/39).

About the outcome, major part of the patients was recovered $(69 \% ; 27 / 36)$, of these: $44 \%(16 / 36)$ showed partial improvement of symptoms and was discharged or transferred for a reference service and 25\% (9/36) showed full recovery and was discharged of the hospital. In relation to mortality, in the sample happens ten deaths $(28 \%)$, of these: seven $(19 \%)$ had directly connection with the CVT, two $(6 \%)$ with indirectly connection and one $(3 \%)$ don't have any connection whit the CVT. Three (8\%) patients went to coma and two $(6 \%)$ died, three cases had no reported prognosis.

\section{Conclusion}

CVT is a rare and severe complication in COVID 19. Clinical signs such as headache, mental confusion, aphasia and hemiparesis should raise suspicion of CVT, seeing that the consequences of this condition are potentially fatal. Moreover, in cases where there is an increase in the levels of D-dimer, fibrinogen and C-reactive protein, associated with neurological symptoms, imaging examinations should be performed to confirm the diagnosis. In addition, with a high suspicious or CVT confirmed, the treatment must be started. The anticoagulant therapy is the treatment for some cases and thrombectomy may be useful for severe CVT. It should also be mentioned that data in the literature on the topic are still scant, requiring more studies into the investigation of CVT associated with COVID-19, evaluating the epidemiology, physiopathology, diagnosis, the management and the outcome of the condition.

\section{Acknowledgments}

None.

\section{Conflicts of interest}

The authors declare that they have no conflicts of interests.

\section{References}

1. Huang C, Wang Y, Li X, et al. Clinical features of patients infected with 2019 novel coronavirus in Wuhan, China. The Lancet. 2020;395(10223):497506.

2. Coronavirus Update (Live): 137,464,817 Cases and 2,962,554 Deaths from COVID-19 Virus Pandemic - Worldometer. 2021.

3. Cui J, Li F, Shi ZL. Origin and evolution of pathogenic coronaviruses. Nature Reviews Microbiology. 2019;17(3):181-192.

4. Qiang XL, Xu P, Fang G, et al. Using the spike protein feature to predict infection risk and monitor the evolutionary dynamic of coronavirus. Infect Dis Poverty. 2020;9(1):1-8.

5. Seyed E, Riahi N, Nikzad H. The novel coronavirus Disease-2019 (COVID-19): Mechanism of action, detection and recent therapeutic strategies. Virology. 2020;551(January):1-9.

6. Koralnik IJ, Tyler KL. COVID-19: A Global Threat to the Nervous System. Ann of Neurol. 2020;88(1):1-11.
7. Manolis AS, Manolis TA, Manolis AA, et al. COVID-19 Infection: Viral Macro- and Micro-Vascular Coagulopathy and Thromboembolism/ Prophylactic and Therapeutic Management. J Cardiovasc Pharmacol Ther. 2021;26(1):12-24.

8. Nicola M, Di D, Calcaterra I, et al. Hemostatic Changes in Patients with COVID-19: A Meta-Analysis with Meta-Regressions. $J$ clin med. 2020;9(7):1-21.

9. Vidali S, Morosetti D, Cossu E, et al. D-dimer as an indicator of prognosis in SARS-CoV-2 infection: a systematic review. ERJ Open Research. 2020;6(2):00260-02020.

10. Lodigiani C, Iapichino G, Carenzo L, et al. Venous and arterial thromboembolic complications in COVID-19 patients admitted to an academic hospital in Milan, Italy. Thromb Res. 2020;191:9-14.

11. Klok FA, Kruip MJHA, van der Meer NJM, et al. Incidence of thrombotic complications in critically ill ICU patients with COVID-19. Thrombosis Research. 2020;191:148-150.

12. Cavalcanti DD, Raz E, Shapiro M, et al. Cerebral venous thrombosis associated with COVID-19. Am J Neuroradiol. 2020;41(8):1370-1376.

13. Tu TM, Goh C, Tan YK, et al. Cerebral Venous Thrombosis in Patients with COVID-19 Infection: a Case Series and Systematic Review. $J$ Stroke Cerebrovasc Dis. 2020;29(12):105379.

14. Abouhashem S, Eldawoody H, Taha MM. Cerebral venous sinus thrombosis in patients with COVID-19 infection. Interdisciplinary Neurosurgery: Advanced Techniques and Case Management. 2021;24.

15. Dakay K, Cooper J, Bloom J, et al. Cerebral Venous Sinus Thrombosis in COVID-19 Infection: A Case Series and Review of The Literature. $J$ Stroke Cerebrovasc Dis. 2021;30:105434.

16. Hughes C, Nichols T, Pike M, et al. Cerebral Venous Sinus Thrombosis as a Presentation of COVID-19. Eur J Case Rep Intern Med. 2020;7(5):001691.

17. Xiong M, Liang X, Wei YD. Changes in blood coagulation in patients with severe coronavirus disease 2019 (COVID-19): a meta-analysis. $\mathrm{Br} \mathrm{J}$ Haematol. 2020;189(6):1050-1052.

18. Por A, Valeriani E, Pola R, et al. Venous thromboembolism in patients with COVID-19: Systematic review and meta-analysis. Thrombosis Research. 2020;196:67-74.

19. Stam J. Thrombosis of the Cerebral Veins and Sinuses. $N$ Engl J Med. 2005;352(17):1791-1798.

20. Favas TT, Dev P, Chaurasia RN, et al. Neurological manifestations of COVID-19: a systematic review and meta-analysis of proportions. Neurological Sciences. 2020;41(12):3437-3470.

21. Baldini T, Asioli GM, Romoli M, et al. Cerebral venous thrombosis and severe acute respiratory syndrome coronavirus- 2 infection: A systematic review and meta-analysis. Eur J Neurol. 2021:1-13.

22. Silvis SM, de Sousa DA, Ferro JM, et al. Cerebral venous thrombosis. Nat Rev Neurol. 2017;13(9):555-565.

23. Román GC, Spencer PS, Reis J, et al. The neurology of COVID-19 revisited: A proposal from the Environmental Neurology Specialty Group of the World Federation of Neurology to implement international neurological registries. Journal of the Neurological Sciences. 2020;414:116884.

24. Abdalkader M, Shaikh SP, Siegler JE, et al. Cerebral Venous Sinus Thrombosis in COVID-19 Patients: A Multicenter Study and Review of Literature. Journal of Stroke and Cerebrovascular Diseases. 2021;30(6):105733.

25. Nasr DM, Brinjikji W, Cloft HJ, et al. Mortality in cerebral venous thrombosis: Results from the national inpatient sample database. Cerebrovasc Dis. 2013;35(1):40-44.

26. Haghighi AB, Edgell RC, Cruz-Flores S, et al. Mortality of cerebral venoussinus thrombosis in a large national sample. Stroke. 2012;43(1):262-264. 
27. Baudar C, Duprez T, Kassaba A, et al. COVID-19 as triggering co-factor for cortical cerebral venous thrombosis? J Neuroradiol. 2020;48(1):6567.

28. Dobesh PP, Trujillo TC. Coagulopathy, Venous Thromboembolism and Anticoagulation in Patients with COVID-19. Pharmacotherapy. 2020;40(11):1130-1151.

29. Hulswit RJG, Haan CAM de, Bosch B-J. Coronavirus Spike Protein and Tropism Changes. Adv Virus Res. 2020;96:29-57.

30. Khan IH, Savarimuthu S, Leung MST, et al. The need to manage the risk of thromboembolism in COVID-19 patients. J Vasc Surg. 2020;72(3):799 804.

31. Dakay K, Cooper J, Bloomfield J, et al. Cerebral Venous Sinus Thrombosis in COVID-19 Infection: A Case Series and Review of The Literature. $J$ Stroke Cerebrovasc Dis. 2021;30(1):105434.

32. Tal S, Spectre G, Kornowski R, Perl L. Venous Thromboembolism Complicated with COVID-19: What Do We Know so Far? Acta Haematologica. 2020;143(5):417-424.

33. Eschera R, Breakeya N, Lämmle B. Severe COVID-19 infection associated with endothelial activation. Thrombosis Research. 2020;190:62.

34. Michael B, Vikse J, Benoit S, et al. Hyperinflammation and derangement of renin-angiotensin-aldosterone system in COVID-19: A novel hypothesis for clinically suspected hypercoagulopathy and microvascular immunothrombosis. Clinica Chimica Acta. 2020;507:167-173.

35. Chen X, Yang X, Zheng Y, et al. SARS coronavirus papain-like protease inhibits the type I interferon signaling pathway through interaction with the STING-TRAF3-TBK1 complex. Protein and Cell. 2014;5(5):369381.

36. Speeckaert MM, Speeckaert R, Delanghe JR. Potential underlying mechanisms of cerebral venous thrombosis associated with COVID-19. $J$ Neuroradiol. 2020;47:473-476.

37. Manolis AS, Manolis TA, Manolis AA, et al. COVID-19 Infection: Viral Macro- and Micro-Vascular Coagulopathy and Thromboembolism/ Prophylactic and Therapeutic Management. J Cardiovasc Pharmacol Ther. 2021;26(1):12-24.

38. Klein DE, Libman R, Kirsch $\mathrm{C}$, et al. Cerebral venous thrombosis: Atypical presentation of COVID-19 in the young. Journal of Stroke and Cerebrovascular Diseases. 2020;29:104989.

39. Zhou Z, Kang H, Li S, et al. Understanding the neurotropic characteristics of SARS-CoV-2: from neurological manifestations of COVID-19 to potential neurotropic mechanisms. Journal of Neurology. 2020;267(8):2179-2184.

40. Shakibajahromi B, Haghighi AB, Salehi A, et al. Clinical and radiological characteristics and predictors of outcome of cerebral venous sinus thrombosis, a hospital-based study. Acta Neurol Belg. 2020;120(4):845852.d

41. Sugiyama Y, Tsuchiya T, Tanaka R, et al. Cerebral venous thrombosis in COVID-19-associated coagulopathy: A case report. J Clin Neurosci. 2020;79:30-32.

42. Mikaberidze A. Cerebral venous sinus thrombosis might be under-diagnosed in the COVID-19 era. International Journal of Phytoremediation. 2007;20(1):135-136.

43. Ferro JM, Canhão P. Cerebral Venous Sinus Thrombosis: Update on Diagnosis and Management. Current Cardiology Reports. 2014;16(9):110 .

44. Al-Ani F, Chehade S, Lazo-Langner A. Thrombosis risk associated with COVID-19 infection. A scoping review. Thrombosis Research. 2020;192:152-160.

45. Kow CS, Zaihan AF, Hasan SS. Anticoagulant approach in COVID-19 patients with cerebral venous thrombosis. J Stroke Cerebrovasc Dis. 2020;29(12):105222.
46. Pang YZ, Shafi H, Lee ZC, et al. Cerebral venous thrombosis in a patient with mild COVID-19 infection. Ann Acad Med Singap. 2021;50(2):188190

47. Ferro JM, Coutinho JM, Dentali F, et al. Safety and Efficacy of Dabigatran Etexilate vs Dose-Adjusted Warfarin in Patients with Cerebral Venous Thrombosis: A Randomized Clinical Trial. JAMA Neurology. 2019;76(12):1457-1465.

48. Guendouz C, Quenardelle V, Riou-Comte N, et al. Pathogeny of cerebral venous thrombosis in SARS-Cov-2 infection. Medicine. 2021;100(10):e24708.

49. Tang N, Bai H, Chen X, et al. Anticoagulant treatment is associated with decreased mortality in severe coronavirus disease 2019 patients with coagulopathy. J Thromb Haemost. 2020;18(5):1094-1099.

50. Kananeh MF, Thomas T, Sharma K, et al. Arterial and venous strokes in the setting of COVID-19. J Clin Neurosci. 2020;79:60-66.

51. Natoli S, Oliveira V, Calabresi P, et al. Does SARS-Cov-2 invade the brain? Translational lessons from animal models. Eur J Neurol. 2020;27(9):1764-1773.

52. Janardhan V, Janardhan V, Kalousek V. COVID-19 as a Blood Clotting Disorder Masquerading as a Respiratory Illness: A Cerebrovascular Perspective and Therapeutic Implications for Stroke Thrombectomy. Journal of Neuroimaging. 2020;30(5):555-561.

53. Zaidat OO, Castonguay AC, Linfante I, et al. First pass effect: A new measure for stroke thrombectomy devices. Stroke. 2018;49(3):660-666.

54. Escalard S, Maiër B, Redjem H, et al. Treatment of Acute Ischemic Stroke due to Large Vessel Occlusion with COVID-19: Experience from Paris. Stroke. 2020;51(8):2540-2543.

55. Beretta S, da Re F, Francioni V, et al. Case Report: Concomitant Massive Cerebral Venous Thrombosis and Internal Iliac Vein Thrombosis Related to Paucisymptomatic COVID-19 Infection. Frontiers in Neurology. 2021;12:10-13.

56. Reza Ostovan V, Foroughi R, Rostami M, et al. Cerebral venous sinus thrombosis associated with COVID-19: a case series and literature review. Journal of Neurology. 123AD;1:3.

57. Al-ani F, Lazo-langner A. Thrombosis risk associated with COVID-19 infection. A scoping review. Thrombosis Research. 2020;169:152-160.

58. Ferro JM, Canhão P. Cerebral Venous Sinus Thrombosis: Update on Diagnosis and Management. Current Cardiology Reports. 2014;16(9):523.

59. Garaci F, Giuliano F di, Picchi E, et al. Venous cerebral thrombosis in COVID-19 patient. J Neurol Sci. 2020;414:116871.

60. Hemasian H, Ansari B. First case of Covid-19 presented with cerebral venous thrombosis: A rare and dreaded case. Revue Neurologique. 2020;176(6):516-525

61. Asif R, O’Mahony MS. Rare complication of COVID-19 presenting as isolated headache. BMJ Case Reports. 2020;13(10):1-3.

62. Logan M, Leonard K, Girzadas D. Case Report of Cerebral Venous Thrombosis as a Complication of Coronavirus Disease 2019 in a Wellappearing Patient. Clin Pract Cases Emerg Med. 2021;5(1):2019-2022.

63. Kaur I, Vyas C, Mughal M, et al. Cerebral Venous Sinus Thrombosis in COVID-19: An Unusual Presentation. Cureus. 2021;13(3):8-10.

64. Cardoso ER, Bains SS, Robison B, et al. Superficial cerebral venous thrombosis and intracerebral hematoma in a 48-year-old man with sars-cov-2 infection: A case report. American Journal of Case Reports. 2021;22(1):1-7.

65. Haroon KH, Muhammad A, Hussain S, et al. COVID-19 Related Cerebrovascular Thromboembolic Complications in Three Young Patients. Case Reports in Neurology. 2020;12:321-328. 
66. Hussain S, Vattoth S, Haroon KH, et al. A Case of Coronavirus Disease 2019 Presenting with Seizures Secondary to Cerebral Venous Sinus Thrombosis. Case Reports in Neurology. 2020;12(2):260-265.

67. Malentacchi M, Gned D, Angelino V, et al. Concomitant brain arterial and venous thrombosis in a COVID-19 patient. European Journal of Neurology. 2020;27(9):e38-e39.

68. Poillon G, Obadia M, Perrin M, et al. Cerebral venous thrombosis associated with COVID-19 infection: Causality or coincidence? $J$ Neuroradiol. 2020;48(2):121-124.

69. Thompson A, Morgan C, Smith P, et al. Cerebral venous sinus thrombosis associated with COVID-19. Practical Neurology. 2021;21(1):75-76.

70. Bastidas HI, Márquez-Pérez T, García-Salido A, et al. Cerebral venous sinus thrombosis in a pediatric patient with COVID-19. Neurology: Clinical Practice. 2020;11(2):e208-e210.

71. Ramesh SV, Ramesh PV, Ramesh MK, et al. COVID-19-associated papilledema secondary to cerebral venous thrombosis in a young patient. Indian J Ophthalmol. 2021;69(3):770-772.

72. Loos CMJ, Yperzeele L, Jadoul C, et al. Deep cerebral venous sinus thrombosis with transient antiphospholipid antibodies in COVID-19 disease. Acta Neurologica Belgica. 2021;121(1):291-293.
73. Beretta S, da Re F, Francioni V, et al. Case Report: Concomitant Massive Cerebral Venous Thrombosis and Internal Iliac Vein Thrombosis Related to Paucisymptomatic COVID-19 Infection. Frontiers in Neurology. 2021;12:10-13.

74. Rigamonti A, Mantero V, Piamarta F, et al. Cerebral venous thrombosis associated with coronavirus infection: an underestimated entity? Neurological Sciences. 2021;42(1):317-318.

75. Roy-Gash F, de Mesmay M, Devys JM, et al. COVID-19-associated acute cerebral venous thrombosis: clinical, CT, MRI and EEG features. Critical Care. 2020;24(1):1-3

76. Bolaji P, Kukoyi B, Ahmad N, et al. Extensive cerebral venous sinus thrombosis: A potential complication in a patient with COVID-19 disease. BMJ Case Reports. 2020;13(8):13-16.

77. Nwajei F, Anand P, Abdalkader M, et al. Cerebral Venous Sinus Thromboses in Patients with SARSCoV-2 Infection: Three Cases and a Review of the Literature. J Stroke Cerebrovasc Dis. 2020;29(12):105412. 